\title{
Design and Construction of a Biohydrogen and Bioethanol Production System from the Biomass of the Eichhornia Crassipes
}

\author{
Uriel Fernando Carreño Sayago ${ }^{1}$, Camila Rodríguez ${ }^{2}$ \\ 1 Universidad los Libertadores ufcarrenos@libertadores.edu.co \\ 2 Universidad los Libertadores crodriguezpa@libertadores.edu.co \\ * Correspondence: ufcarrenos@libertadores.edu.co
}

\begin{abstract}
Introduction: Biofuels, biohydrogen and bioethanol have properties that stand out from other fossil fuels, are colorless, odorless, and insipid, therefore, they are free of contaminants. Its production can be generated from the biomass of the aquatic plant Eichhornia crassipes, since this alternative is timely and viable due to its high energy composition. This plant is a problem in wetlands, rivers and other hydrosystems, due to its abundance and dominance over other species of aquatic plants, and which in effect causes an ecological imbalance. Objective: To evaluate the production of biohydrogen and bioethanol from the biomass of the E. crassipes plant. Materials and methods: Lignocellulosic material was used, realizing different physical, chemical and biological processes such as: reduction of size, lignin removal, acid hydrolysis, fermentation and distillation. a laboratory scale production system was designed and built where two bioreactors were used in the process. Results and discussion: the production of bioethanol and biohydrogen showed a production index of more than $40 \mathrm{mg}$ of bioethanol per gram of bio-mass of E. crassipes and in relation to biohydrogen, $65 \mathrm{mmol} / \mathrm{L}$ was obtained. Conclusion: With the biomass of E. crassipes it is possible to obtain a high index of bio-fuel production, since it is possible to take advantage of its physical characteristics and its high proliferation in hydrosystems, in this way it constitutes an optimal alternative to produce biohydrogen and bioethanol at a high scale.
\end{abstract}

Keywords: bioreactor; hydrolysis; fermentation; biofuels

\section{Introduction}

An alternative to the use of oil, coal and nuclear reactors, as an energy source, is the use of biofuels produced from vegetable waste, as they are a renewable, abundant and clean energy. Due, the importance of the production of energies such as biohydrogen and bioethanol is generated.

Hydrogen has unusual properties because it is a clean and green biofuel, it is colorless, odorless, and insipid, therefore it is free of contaminants such as $\mathrm{CH} 4$ (metano) and $\mathrm{CO} 2$ (carbon dioxide), it is used in different industries of chemical processes, since its only compound is water [1-2].

Its production through dark fermentation is a promising path from raw materials rich in carbohydrates (such as wastewater, food waste and agricultural waste) [3].

Dark fermentation to produce hydrogen from various types of biomass has been widely studied and generally demonstrated with mixed microbial cultures, since they are more productive and therefore more applicable to large-scale operations than pure crops. to its greater capacity to use mixtures of substrates and to allow the balanced metabolic flow, in addition the production of biohydrogen with mixed cultures does not require sterilization, which is beneficial for the industrialization [4-8]. 
On the other hand, the production of fuel ethanol from lignocellulosic material has become a highly viable alternative that could open new markets for its revaluation [9] In this production, different physical, chemical and biological processes take place, such as: size reduction, lignin removal, acid hydrolysis, fermentation and distillation [10]

One of the ways to produce ethanol is by fermentation, from raw materials rich in carbohydrates (sugar, starch, cellulose, etc.). For this reason, it is common to designate the ethanol obtained by this route: "bioethanol" [11]

Currently, bioethanol is produced by alcoholic fermentation of sugars present in renewable materials, which is influenced by factors such as the concentration of sugars in the substrate and the fermenting microorganism that is used. According to the studies of [12] together with [13] it has been determined that when Sacharomyces cerevisiae is cultivated at high concentrations of sugar (less than $30-40 \%$ ) the production of ethanol is increased.

One of the main drawbacks, when producing biofuels, is the use of food for humans and animals as raw material, therefore, in different studies have been characterized some materials such as wood and nutshell that have high percentages of cellulose and low levels of lignin.

According to the above, a plant that has the necessary amount of cellulose and hemicellulose, and that is not human food, which is Eicchornia crassipes, was investigated.

From the biomass of the E. crassipes, in the present investigation was designed and built, and analyzed the biohydrogen and bioethanol production processes at pilot laboratory scale. Developing a bioreactor for the hydrolysis of the dry biomass of this plant and two bioreactors were designed, one for dark fermentation and the other for alcohol fermentation.

\section{Materials and Methods}

After having carried out a bibliographic review worldwide, about the design of bioreactors, they gave way to the development of these in the present investigation, in order to obtain a clean production of biofuels.

To obtain the biofuels, first, the hydrolysis of lignocellulolytic material was carried out and then the production of bioethanol and biohydrogen was carried out.

The hydrolyzed bioreactor is made of glass, its capacity is 5 liters, it has a lid for gas evolution, sampling of $\mathrm{pH}$ and temperature, together with a magnetic stirring heater at $120 \mathrm{RPM}$ at a temperature of $60^{\circ} \mathrm{C}$.

To this bioreactor the E. crassipes was dried and crushed in an amount of $200 \mathrm{gr}$ where it was mixed with distilled water. The samples reacted in $1 \%(\mathrm{w} / \mathrm{v})$ of caustic soda $(\mathrm{NaOH})$ at a temperature of $60^{\circ} \mathrm{C}$, during $12 \mathrm{~h}$, afterwards the samples were washed with tap water until reaching the $\mathrm{pH}$ value of the water. Then sulfuric acid $(\mathrm{H} 2 \mathrm{SO} 4) 3 \%(\mathrm{v} / \mathrm{v})$ was added at a temperature of $60^{\circ} \mathrm{C}$, during $12 \mathrm{~h}$, the samples were washed with distilled water until reaching a neutral $\mathrm{pH}$.

The content of reducing sugars was determined by the Salicylic Dinitro Acid (DNS) method [14] which indirectly quantifies substrate consumption. In this way, 4 liters of hydrolyzed solution of E. crassipes were obtained for the continuation of bioethanol and biohydrogen production.

The production of sugar through the hydrolysis of 12 hours for $\mathrm{NaOH}$ and 12 hours of $\mathrm{HSO} 4$ was 60 grams / 4L. A relevant production of sugar and registering similar datas in [15] There was a constant production of hydrolysis.

Production of bioethanol. After carrying out the hydrolyzate process in the bioreactor, the bioethanol production process is carried out in the alcohol fermentation bioreactor.

The alcoholic fermentation bioreactor is manufactured in glass and its storage capacity is 5 liters, it is made up of a lid for the evolution of gases, sampling of $\mathrm{pH}$ and temperature, with heater. The magnetic stirring is carried out at $120 \mathrm{RPM}$ at a temperature of $60^{\circ} \mathrm{C}$. In this process, $\mathrm{S}$. cerevisiae was used as inoculum of the fermentor of the hydrolyzate of E. crassipes. Then concentrations of $200 \mathrm{~g} /$ $\mathrm{L}, 250 \mathrm{~g} / \mathrm{L}$ and $300 \mathrm{~g} / \mathrm{L}$ of biomass were evaluated, in order to determine which of these represents the highest percentage of ethanol. 
So, $100 \mathrm{~g}$ of the hydrolyzate were taken to the bioreactor where it was mixed with distilled water and $100 \mathrm{~g}$ of the inoculum were added, then the initial $\mathrm{pH}$ was adjusted to 5.5. The bioreactor was hermetically sealed with rubber septums and aluminum plugs. During the fermentation of the hydrolysis of the biomass, ethanol percentage tests were performed by gas chromatography at time intervals of 5 hours, as shown in graph 1, in the results.

According to the previous procedure, the steps for the other two concentrations ( $250 \mathrm{~g} / \mathrm{L}$ and $300 \mathrm{~g} / \mathrm{L}$ ) were repeated and the results obtained in the same graph 1 can be observed.

Production of biohydrogen. The same bioethanol procedure was carried out in the hydrolyzate bioreactor for this production and the dark fermentation bioreactor was used at a temperature of $30^{\circ} \mathrm{C}$.

The bioreactors were hermetically sealed with rubber septa and aluminum plugs, in addition the orifices of the bottles were purged with nitrogen for 5 minutes to ensure the anaerobic condition. In each time interval, the volume of biogas was measured by the displacement of the plunger method. The hydrogen gas was de-terminated by gas chromatography using a TCD detector in a GC-Agilent 7890 brand chromatograph.

The biosolids generated in the Wastewater Treatment Plant (WWTP), the saltpeter from the city of Bogotá, were taken as inoculants. These biosolids are obtained after digestion after 20 days of treatment and were used due to the appropriate conditions. of its bacterial profile (Chuang et al., 2011).

Two assemblies were made in the bioreactors, for continuous production of biohydrogen in the same conditions to establish productivity. $200 \mathrm{~g}$ of the hydrolyzate were taken to each bioreactor where they were mixed with distilled water and $100 \mathrm{~g}$ of the inoculum (biosolid) was added, and the initial $\mathrm{pH}$ was adjusted to 5.5.

Four different tests were carried out in the two bioreactors, establishing the productivity and standardizing the ideal time in the bioreactor.

\section{Results}

A greater production of ethanol is observed for the $300 \mathrm{~g} / \mathrm{L}$ samples compared to the $250 \mathrm{~g} / \mathrm{L}$ and $200 \mathrm{~g} / \mathrm{L}$ samples in a time of 25 hours. The final determination of ethanol obtained is shown in graph 1.

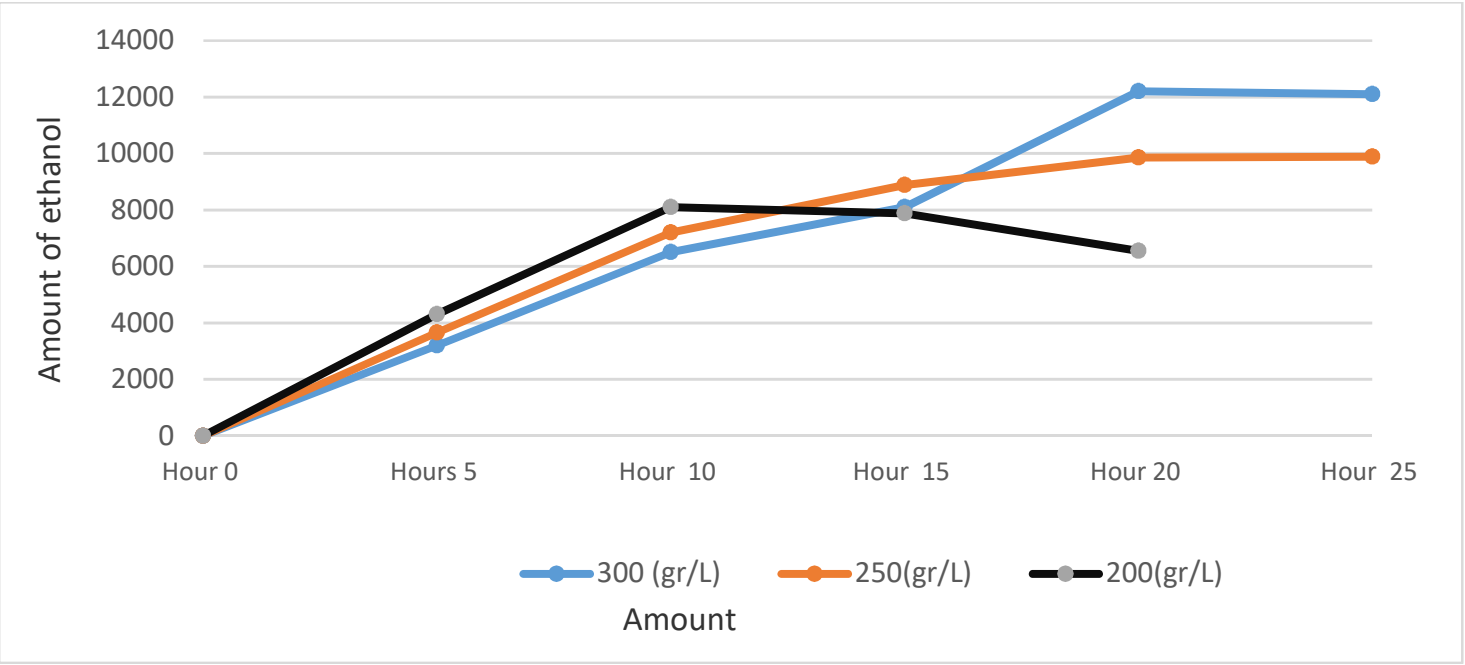

Figure 1. Ethanol productivity with different amounts of hydrolysed biomass

Concentrations with less amount of hydrolysed biomass started to produce more ethanol than the amount of $300 \mathrm{gr} / \mathrm{L}$. during the first 10 hours, maintaining a constant production during that 
time, under the design conditions but with different types of hydrolyzing agents [16], obtained similar results.

The concentration of $200 \mathrm{~g} / \mathrm{L}$ decreases in its entirety at hour 20 with a final ethanol production of about 6,552 $\mathrm{mg} / \mathrm{L}$, and a yield of $32.76 \mathrm{mg}$ of ethanol is obtained for each gram of E. crassipes. These results were similar to the experiments of [17], where they used Clostridium thermo-cellum to produce $9.72 \mathrm{mg} / \mathrm{L}$.

The concentration of $250 \mathrm{gr} / \mathrm{L}$ continues its production after 10 o'clock until 25 hours of production with an ethanol result of $9,888 \mathrm{mg} / \mathrm{L}$ and a yield of $39.6 \mathrm{mg}$ of ethanol per gram of $\mathrm{E}$ is obtained. crassipes. [18], obtained results with similar bioreactors but with P. tannophilus reaching a maximum ethanol concentration of $4.3 \mathrm{~g} / \mathrm{L}$, followed by $2.1 \mathrm{~g} / \mathrm{L}$, results well below those reported in this investigation.

The concentration of $300 \mathrm{gr} / \mathrm{L}$ obtained a production of $12,100 \mathrm{mg} / \mathrm{L}$ of ethanol in the total time of the process, and a yield of $40.3 \mathrm{mg}$ of ethanol is obtained for each gram of E. crassipes.

[19], they used Aspergillus Nigercelulasa as transforming agent of the hydrolyzed biomass of E. crassipes, reporting $20 \%$ more than those experimented in this research, but this bacterium is more difficult to isolate than the Sacharomy-ces.

Table 1 shows the biohydrogen production of the two bioreactors called $x 1$ and $x 2.14$ samples were taken every 12 hours, where the samples represent the productivity tests, obtaining an arithmetic average and a standard deviation of each process.

In the bioreactor $\mathrm{x} 2$ there was an imbalance and only 9 samples were taken from the biohydrogen production process.

As can be seen in Table 1, an average production value of $68.5 \mathrm{mmol} \mathrm{H} 2$ / $\mathrm{L}$ was obtained in the bioreactor $\mathrm{x} 1$ and in the bioreactor $\mathrm{x} 2$ an average production of $65.6 \mathrm{mmol} / \mathrm{H} 2$ was obtained.

In these bioreactors, the Ptar biosolids were used as a microbial inoculum for the production of biohydrogen.

Table 1 Production of Biohydrogen in bioreactors.

\begin{tabular}{lll}
\hline & X1(mmol $)$ & X2(mmol) \\
\hline sample 1 & 98 & 100 \\
sample 2 & 52 & 98 \\
sample 3 & 87 & 111 \\
sample 4 & 80,3 & 85 \\
sample 5 & 72 & 63 \\
sample 6 & 63 & 52 \\
sample 7 & 59 & 53,3 \\
sample 8 & 59,6 & 23 \\
sample 9 & 58,6 & 1 \\
sample 10 & 55,2 & \\
sample 11 & 45 &
\end{tabular}




$\begin{array}{lll}\text { sample } 12 & 32 & \\ \text { sample 13 } & 21 & \\ \text { sample 14 } & 2 & 65,1 \\ \text { Average } & 68,5 & 35,0 \\ \text { standard } & 14,5 & \\ \text { deviation } & & \end{array}$

From the above we can observe a constant productivity of biohydrogen in reactor 1 and 2 with similar averages and a very low standard deviation, demonstrating that the process was done with a high reliability.

In the following Figure 2 you can see the samples taken and how the productivity of biohydrogen decreases in the two reactors

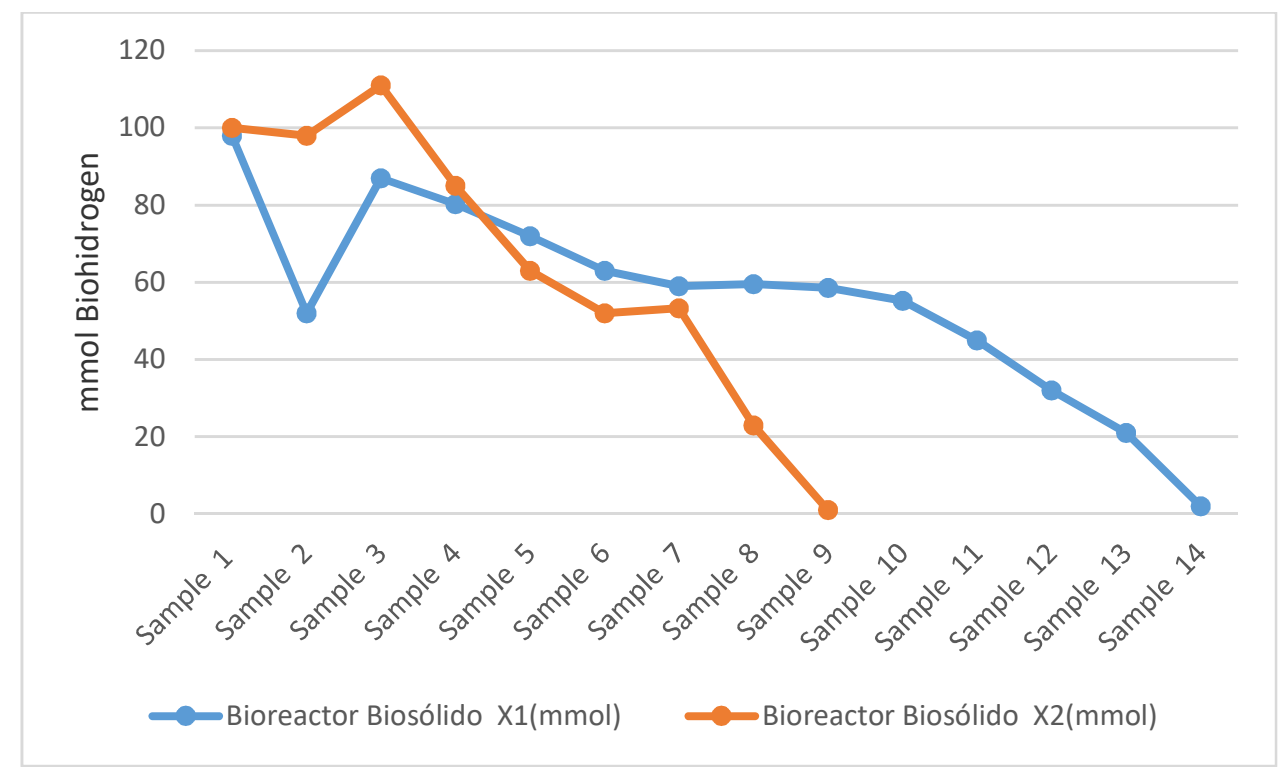

Figure 2. Continuous production of biohydrogen

Subsequently, a biohydrogen production was carried out for $100 \mathrm{~g}$ of hydrolyzed biomass, an approximate $65 \mathrm{mmol} / \mathrm{L}$ of biohydrogen is produced with the inoculum of biosolids. There is a standard productivity of biohydrogen from the Eichhornia crassipes of 7 days. [20], obtained results similar to this research using also PTAR sludge.

[21] Obtained results above $50 \%$ of this research, showing that the hydrolysis process was better, but Mechery and Sylas, (2016), also obtained results due to the use of Pseudonomas.

\section{Conclusions}


It is possible to establish that the hydrolyzed biomass of E. crassipes has a high percentage of reducing sugars and consequently its glucosed syrups produce a high content of bioethanol and biohydrogen.

The yield in obtaining these biofuels, from this biomass is relevant for the production of energy, taking into account that the E. crassipes is one of the waste not used and of high quantity in the wetlands, rivers and de-more hydrosystems, so it could be located in an alternative of high interest for the large-scale production of biofuels.

Biofuels have a high potential for the development of energy systems, and their advantage is that they do not present environmental hazards in their production. This production with E. crassipes has a high energy efficiency, the environmental impact it produces is great and its profitability is effective.

It is proposed to carry out a greater production of biohydrogen, to establish prevailing statistical models in order to optimize the production of this compound, so that it becomes a strong potential for alternative energy.

\section{References}

[1] Khan, M. A., Ngo, H. H., Guo, W., Liu, Y., Zhang, X., Guo, J., ... \& Wang, J. (2017). Biohydrogen production from anaerobic digestion and its potential as renewable energy. Renewable Energy. 98,221-225. doi: 10.1016/j.renene.2017.04.029

[2] Rahman, S. N. A., Masdar, M. S., Rosli, M. I., Majlan, E. H., Husaini, T., Kamarudin, S. K., \& Daud, W. R. W. (2016). Overview biohydrogen technologies and application in fuel cell technology. Renewable and Sustainable Energy Reviews, 66, 137-162. doi: doi.org/10.1016/j.rser.2016.07.047

[3] Ri, P. C., Ren, N. Q., Ding, J., Kim, J. S., \& Guo, W. Q. (2017). CFD optimization of horizontal continuous stirred-tank (HCSTR) reactor for bio-hydrogen production. International Journal of Hydrogen Energy, 42(15), 9630-9640. doi: 10.1016/j.ijhydene.2017.02.035

[4] García-Depraect, O., Gómez-Romero, J., León-Becerril, E., \& López-López, A. (2017). A novel biohydrogen production process: Co-digestion of vinasse and Nejayote as complex raw substrates using a robust inoculum. International Journal of Hydrogen Energy, 42(9), 5820-5831. doi: 10.1016/j.ijhydene.2016.11.204

[5] Dessì, P., Lakaniemi, A. M., \& Lens, P. N. (2017). Biohydrogen production from xylose by fresh and digested activated sludge at 37,55 and $70^{\circ} \mathrm{C}$. Water research, 115, 120-129. doi: 10.1016/j.watres.2017.02.063

[6] Kuldiloke, J., Eshtiaghi, M. N., Peeploy, P., \& Amornrattanapong, P. (2010). Bioconversion of water hyacinth (Eichhornia crassipes) to bioethanol. Journal of ISSAAS [International Society for Southeast Asian Agricultural Sciences](Philippines). Retrieved from http://agris.fao.org/agrissearch/search.do?recordID=PH2013000169

[7] Chuang, Y. S., Lay, C. H., Sen, B., Chen, C. C., Gopalakrishnan, K., Wu, J. H., ... \& Lin, C. Y. (2011). Biohydrogen and biomethane from water hyacinth (Eichhornia crassipes) fermentation: effects of substrate concentration and incubation temperature. international journal of hydrogen energy, 36(21), 14195-14203. doi: 10.1016/j.ijhydene.2011.04.188

[8] Hernández Avilés, D. M., Grisales Penagos, D. K., Tatiana, A., \& Chaparro, R. (2016). Efecto de la configuración de reactores anaerobios de alta tasa en la producción de hidrógeno: biomasa fija y UASB-híbrido. Revista Ion, 29(1), 27-36. doi: 10.18273/revion.v29n1-2016002

[9] Abdel-Fattah, A. F, \& Abdel-Naby, M. A. (2012). Pretreatment and enzymic saccharification of water hyacinth cellulose. Carbohydrate polymers, 87(3), 2109-2113. doi: 10.1016/j.carbpol.2011.10.033

[10] Benítez, L. T., Tovar, C. T., Ortiz, Á. V., Dunoyer, A. T., Alvear, M., Castillo, C., ... \& Madariaga, N. (2010). Producción de bioetanol a partir de la fermentación alcohólica de jarabes glucosados derivados de cáscaras de naranja y piña. Revista Educación en Ingeniería, 5(10), 120-125. doi: 10.26507/rei.v5n10.104 
[11] Kumar, A., Singh, L. K., \& Ghosh, S. (2009). Bioconversion of lignocellulosic fraction of waterhyacinth (Eichhornia crassipes) hemicellulose acid hydrolysate to ethanol by Pichia stipitis. Bioresource Technology, 100(13), 3293-3297. doi: 10.1016/j.biortech.2009.02.023

[12] Cuervo, L., Folch, J. L., \& Quiroz, R. E. (2009). Lignocelulosa como fuente de azúcares para la producción de etanol. BioTecnología, 13(3), 11-25. Recuperado de https://www.researchgate.net/profile/Jorge_Folch-

[13] Ganguly, A., Chatterjee, P. K., \& Dey, A. (2012). Studies on ethanol production from water hyacinth-A review. Renewable and Sustainable Energy Reviews, 16(1), 966-972. doi: 10.1016/j.rser.2011.09.018

[14] Peña, C., \& Arango, R. (2009). Evaluación de la producción de etanol utilizando cepas recombinantes de Saccharomyces cerevisiae a partir de melaza de caña de azúcar. Dyna, 76(159), 153-161. Recuperado de https://revistas.unal.edu.co/index.php/dyna/article/view/13051

[15] Magdum, S.M., More, A.A. \& Nadaf. (2012). Biochemical conversion of acid pretreatment water hyacinth (eichonnia crassipes) to alcohol using pichia stipitis NCIM 3497, International Journal of advanced biotechnology and research, 3(2), 585 - 590. Retrieved from https://ssrn.com/abstract=2200481

[16] Bronzato, GRF, Ziegler, SM, Silva, RC, Cesarino, I., y Leão, AL (2017). Caracterización de la biomasa pretratada de Eichhornia crassipes (jacinto de agua) para la producción de etanol de segunda generación. Cristales Moleculares y Cristales Líquidos , 655 (1), 224-235.

[17] Das, S. P., Gupta, A., Das, D., \& Goyal, A. (2016). Enhanced bioethanol production from water hyacinth (Eichhornia crassipes) by statistical optimization of fermentation process parameters using Taguchi orthogonal array design. International biodeterioration \& biodegradation, 109, 174-184.

[18] Manivannan, A., y Narendhirakannan, RT (2015). Producción de bioetanol a partir de jacinto de agua de maleza acuático (Eichhornia crassipes) mediante fermentación de levadura. Residuos y valorización de la biomasa , 6 (2), 209-216.

[19] Kouwanou, CS, Dossa, CPA, Adjou, ES, Tchobo, FP, Bonou, C., Soumanou, MM, y Sohounhloué, DC (2018). Hidrólisis fisicoquímica y enzimática de Eichhornia crassipes para la producción de bioetanol de segunda generación. American Journal of Chemistry , 8 (2), 41-44.

[20] Anaerob, M. K. C., PATTRA, S., \& SITTIJUNDA, S. (2017). Biohydrogen productions from hydrolysate of water hyacinth stem (Eichhornia crassipes) using anaerobic mixed cultures. Sains Malaysiana, 46(1), 51-58.

[21] Pattra, S., \& Sittijunda, S. (2015). Optimization of factors affecting acid hydrolysis of water hyacinth stem (Eichhornia Crassipes) for bio-hydrogen production. Energy Procedia, 79, 833837. 